\title{
Isolation and characterization of a gene specifically expressed in different metastatic cells and whose deduced gene product has a high degree of homology to a $\mathrm{Ca}^{2+}$-binding protein family
}

\author{
Alexander Ebralidze, Eugene Tulchinsky, ${ }^{1}$ Mariam Grigorian, Anna Afanasyeva, ${ }^{2}$ Viacheslav Senin, ${ }^{2}$ \\ Elena Revazova, ${ }^{2}$ and Eugene Lukanidin \\ Engelhardt Institute of Molecular Biology and ${ }^{1}$ Institute of Developmental Biology, USSR Academy of Sciences, Moscow; \\ ${ }^{2}$ National Cancer Research Center, USSR Academy of Medical Sciences, Moscow, USSR
}

\begin{abstract}
The gene mts1, which is expressed specifically in metastatic cells, was isolated by molecular cloning coupled with differential DNA reassociation. Transcription of mts1 was found not only in tumor cells, but also in normal cells; homologous RNA was detected only in spleen, thymus, bone marrow, and blood lymphocytes. DNA sequencing of mts 1 revealed an open reading frame containing information for a peptide of 101 amino acids, and the amino acid sequence suggested that the mts 1 protein was identical to the previously isolated $\mathrm{Ca}^{2+}$-binding mouse protein (Jackson-Grusby et al. 1987; Goto et al. 1988). Thus, the mts1 protein is a member of the calcium-modulated protein family, and our data indicate that mts 1 is involved in regulating the metastatic behavior of tumor cells.
\end{abstract}

[Key Words: Mouse metastatic genes; transcription; $m t s 1$; $\mathrm{Ca}^{2+}$-binding proteins]

Received November 30, 1988; revised version accepted April 14, 1989.

Tumor progression is thought to occur when variant cells having selective growth properties arise within a tumor cell population (Foulds 1975). One of the final stages of tumor progression is the appearance of the metastatic phenotype (Nicolson 1984). During metastasis, the tumor cells invade the blood vessels, survive against circulating host immune defenses, and then extravasate, implant, and grow at sites distant from the primary tumor (Nicolson 1982, 1987).

So far, little is known about the intrinsic mechanism involved in the metastatic cascade. It is likely that in some cases the augmented metastatic potential of certain tumor cells may be due to an increased expression of oncogenes, which normally are responsible for control of various cellular functions, including differentiation, proliferation, cell motility, and communication (Cairns 1981; Berger et al. 1988; Klein and Klein 1985). Recently, it has been shown that primary and established rodent fibroblasts transformed by activated oncogene sequences can form metastases (Vousden and Marshall 1984; Thorgiersson et al. 1985; Vousden et al. 1986; Storer et al. 1988); however, not all of the transformed cells expressing activated oncogenes are converted to the metastatic phenotype (Kris et al. 1985; Rotter et al. 1985). These observations indicate that oncogene transforma- tion is not the only mechanism by which transformed cells evolve to the metastatic phenotype, and they imply that other genes can be responsible for the metastatic behavior of transformed cells.

In an attempt to identify such genes, we have been studying an animal model of the metastatic process. Two cell sublines obtained from a spontaneous mouse mammary carcinoma were used. One of the sublines (CSML-0) was derived from a tumor maintained by intramuscular passages and characterized by a low metastatic potential. Solitary lung metastases were detected in less than $10 \%$ of autopsied animals that were killed when in a moribund condition. A second, highly metastatic subline (CSML-100) was created by using the selective method of multiple successive subcutaneous transplantation of metastatic cells into the tail. The frequency of lung metastases by any route of inoculation was $100 \%$. CSML-50 represents an intermediate stage of selection during the establishment of CSML-100. The frequency of lung metastases in this case was about $50 \%$ (Senin et al. 1983, 1984).

The purpose of the present study was to investigate whether the differential expression of genes in both of these sublines can be used to identify genes responsible for the metastatic behavior of CSML-100. Here we re- 
port the results of studies on isolating $m t s 1$, the gene that is expressed specifically in metastatic cells, and we provide evidence that the product of this gene has a high homology with $\mathrm{Ca}^{2+}$-binding proteins and thus is a member of the calcium-modulated protein family.

\section{Results}

Cloning of cDNAs corresponding to mRNAs that are expressed differentially in the CSML-100 and CSML-O cell lines

To examine the differences in gene expression in metastatic and nonmetastatic tumor lines, we used DNA cloning and colony hybridization techniques. Molecular cloning was coupled to differential DNA reassociation to yield a library highly enriched with cDNA molecules specific for metastatic and nonmetastatic cells. Doublestranded cDNA (ds-cDNA) made from CSML-100 poly(A) RNA was cross-hybridized with a 200 -fold excess of a driver CSML-0 poly(A) RNA. To increase the rate of the cDNA/mRNA reassociation reaction, we used the phenol-emulsion reassociation technique (PERT) of Kohne et al. (1977). Most of the cDNA in such conditions hybridized with homologous mRNAs, and less than $5 \%$ of cDNA renatured and formed ds-cDNA molecules. These molecules were ligated to the arms of a $\lambda$ gt 10 vector DNA and, after packaging in a phage coat, were used to infect Escherichia coli. A $\lambda$ gt 10 cDNA library of $\sim 1 \times 10^{4}$ clones was established from poly $(\mathrm{A})^{+}$ mRNAs of CSML-100.

After plating the cDNA library, two sets of replica filters were prepared for in situ hybridization. These were screened differentially with cDNA probes derived from mRNAs of CSML-100 and CSML-0 cell lines. After comparing the resulting pairs of autoradiographs, $1 \times 10^{3}$ clones were selected for further screening on the basis that they gave a high signal after hybridization with the CSML-100-derived probes and a low or zero signal with the CSML-0 probes. Further hybridization analysis indicated that the cDNA inserts could be classified into three groups. The largest group, representing about $90 \%$ of the clones, hybridized equally well with both probes. The second group (about $8 \%$ ) hybridized more intensively with the homologous CSML-100 probes as compared to hybridization with heterologous probes. The third group of the clones (less than $1 \%$ ) hybridized only with the homologous probes. One clone of the latter group, designated as clone mts1, was taken for further analysis.

To determine whether the cloned cDNA represented mRNA sequences, we performed Northern blot analysis on mRNAs isolated from CSML-100 and CSML-0 cells. The results presented in Figure 1 confirmed that the DNA insert in clone mtsl hybridized only to mRNAs isolated from CSML-100 cells. This probe detected a single $0.55-\mathrm{kb}$ transcript.

These data indicate that we have isolated a unique DNA sequence (clone mts1) that is expressed specifically in metastatic cells.

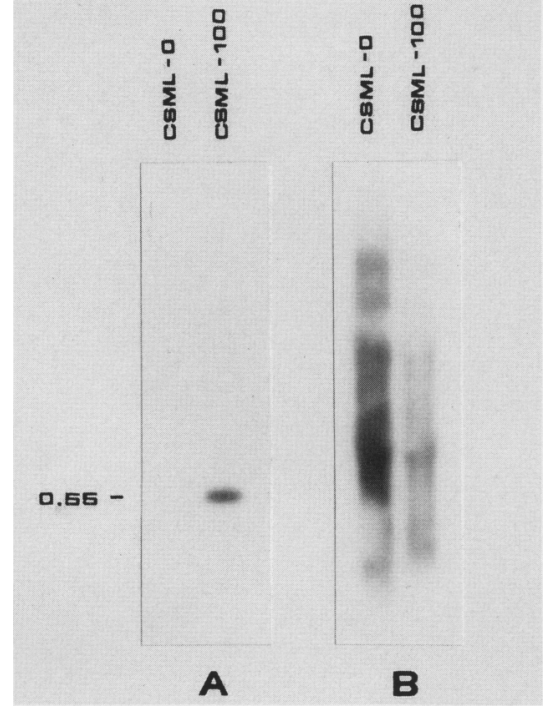

Figure 1. Detection of a $0.55-\mathrm{kb}$ transcript in the CSML-100 cell line. $(A)$ A Northern blot of total RNA $(20 \mu \mathrm{g} / \mathrm{lane})$ isolated from the mouse CSML-100 and CSML-0 cell lines was analyzed by hybridization to the ${ }^{32} \mathrm{P}$-labeled probe of clone $\mathrm{mts} 1 .(B)$ The same filter, after the ${ }^{32}$ P-label was washed out, was rehybridized to the ${ }^{32} \mathrm{P}$-labeled cDNA made from CSML-100 poly $(\mathrm{A})^{+}$ RNA.

DNA insert of clone mtsl represents a single-copy gene

Enzymatic digests of genomic DNA from normal mouse liver and the CSML-100 cell line were probed with ${ }^{32} \mathrm{P}$ labeled mts1 DNA. In both cases, a BamHI fragment of $14 \mathrm{~kb}$ and an EcoRI fragment of $4.4 \mathrm{~kb}$ were detected (Fig. 2A). The patterns obtained with the two DNA preparations were indistinguishable in location and band in tensity. Hybridization of the restriction fragments of genomic.DNA from a variety of other species (human, pig, rat, chicken) indicated the presence of a gene whose sequences cross-hybridize with the mts1 probe (Fig. 2B).

\section{Transcription of $\mathrm{mts} 1$ sequences in tumor and normal} cells

Tumor strains and cell lines used in the present work were checked for their metastatic ability. All transformed cell lines described in the literature as metastatic expressed the metastatic phenotype except one, the melanoma B-16 cell line (Table 1). The phenotype of this tumor strain apparently has changed during many sequential passages in mice, with a resultant loss of metastatic capability.

We investigated the correlation of transcription of $m t s 1$ and the metastatic phenotype of different transformed and normal cells. Northern blot analysis was conducted using the DNA of clone mts1 as a probe. The probe hybridized to the unique 550-base transcript in all the metastatic cell lines analyzed except HMC-Lr. The levels of $m t s 1$ gene expression in both HMC-Lr and nonmetastatic HMC-0 lines were very low (Fig. 3A). The intensity of hybridization was different for each cell line, 


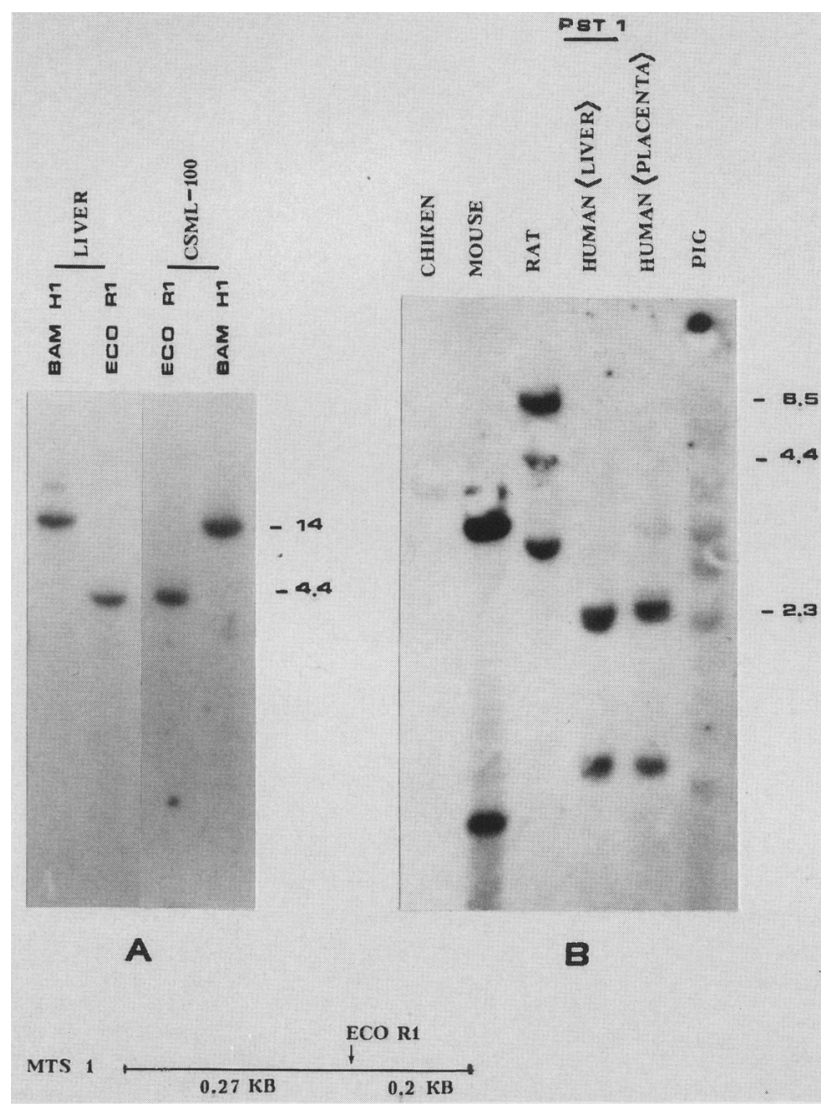

Figure 2. Gel transfer hybridization analysis of DNA from different species. Total DNA was digested with endonucleases, electrophoresed in a $0.8 \%$ agarose gel, transferred to nitrocellulose, and probed with a $0.27-\mathrm{kb}{ }^{32} \mathrm{P}$-labeled EcoRI fragment of clone mts $1|A|$. The $0.27-\mathrm{kb}$ fragment is shown in the schematic diagram of the mtsl clone at the bottom of the figure. $(B)$ Hybridization with ${ }^{32}$ P-labeled DNA of the mtsl clone.

with the strongest hybridization found to RNAs isolated from CSML-100 (Fig. 3B).

The expression of $m t s 1$ depended on the conditions of cell growth. We found that, after five passages in vitro, the level of $m t s 1$-specific RNA in the T36 cell line derived from mice bearing T36 embryocarcinoma was much lower than the expression of these RNAs in the parental tumor (Fig. 3A). The RNA isolated from most nonmetastatic tumors did not hybridize to the ${ }^{32} \mathrm{P}-\mathrm{la}$ beled mts1 probe (Fig. 3A).

We then asked whether the expression of mts1 DNA was specific for transformed cells. RNAs were isolated from different organs of $\mathrm{A} / \mathrm{Sn}$ mice. Northern blot analysis was performed and 550-base mRNAs were detected only in spleen, thymus, bone marrow, and bloodstream lymphocytes (Fig. 4). The amount of RNA expressed in these organs calculated from the intensity of hybridization was low compared with the amount of mRNA in the CSML-100 cell line. It is interesting that hybridized RNA was found only in the so-called 'lymphoid organs' or in lymphocytes.

The influence of DNA methylation on the expression of $m t s 1$ was investigated. The CSML-0 cell line was treated with 5-azacytidine and total RNA was analyzed by Northern blotting with ${ }^{32}$ P-labeled probes of clone mtsl. RNA isolated from the treated and untreated CSML-0 cell lines did not hybridize with the mts1 clone (data not shown). These results suggest that $m t s 1$ transcription is not regulated at the level of DNA methylation.

The protein product of mtsl is very similar to calciumbinding proteins

The nature of the mts1 gene product was identified by comparing its amino acid sequences deduced from the nucleotide sequences in the Protein Sequence Database (Fig. 5A). The amino acid sequence suggested that the mtsl protein was identical to the previously isolated mouse $\mathrm{Ca}^{2+}$-binding protein (Jackson-Grusby et al. 1987; Goto et al. 1988).

Homology was also found with several rat proteins belonging to the family of S-100 related peptides. Especially high homology was found for two rat proteinsp9Ka (Barraclough et al. 1987) and 42A (Masiakowski and Shooter 1988). The only difference between mtsl and these two rat proteins is the substitution of the two amino acid residues. Valine and serine residues at positions 58 and 60 in the mtsl protein are replaced by leucine and asparagine residues in rat proteins.

A $55 \%$ identity in the amino acid sequences was found in $\mathrm{Ca}^{2+}$-binding domains between the S-100 protein and the product of the mts1 gene. An especially high homology was found in the loop part of the domain $(66 \%)$. A homology between the analogous part of the rat intestinal $\mathrm{Ca}^{2+}$-binding protein and the mts1 gene product was $48 \%$ and $63 \%$, respectively (Fig. 5B). The hydrophobicity profiles of S-100, ICaBP, and mtsl were also compared (data not shown). All three profiles are very similar and are in good agreement with the data presented in Masiakowski and Shooter (1988). These data indicate that the mtsl protein is homologous with $\mathrm{Ca}^{2+}$-binding proteins, not only in their amino acid sequences but also in the structural organization of the protein molecules.

\section{Discussion}

In the experiments presented here, a gene that is expressed differentially in tumor metastasis has been identified. PERT was used to enrich specific DNA sequences (Kohne et al. 1977) and the cDNA synthesized on poly(A) ${ }^{+}$RNA from metastatic cells was hybridized in the presence of excess mRNA obtained from nonmetastatic cells. Under these conditions, the bulk of cDNA molecules hybridized with mRNAs and less than $5 \%$ of cDNA was used to reconstruct the recombinant library. Thus, this method increases the relative amount of specific cDNA molecules and simplifies the screening procedure.

We found that the level of mts1 expression correlates with the metastatic potential of tumor cells-the cells 
Table 1. Metastatic potential of analyzed tumors and tumor cell lines

\begin{tabular}{|c|c|c|}
\hline Tumors and cell lines ${ }^{a}$ & $\begin{array}{l}\text { Spontaneous } \\
\text { metastases }\end{array}$ & $\begin{array}{l}\text { Target } \\
\text { organs }\end{array}$ \\
\hline \multicolumn{3}{|l|}{ Mammary carcinosarcoma } \\
\hline CSML-0 & low metastatic ${ }^{b}$ & lung \\
\hline CSML-50 & $50 \%$ & lung \\
\hline CSML-100 & high metastatic ${ }^{c}$ & lung \\
\hline \multicolumn{3}{|l|}{ Mammary solid carcinoma } \\
\hline HMC-0 & low metastatic & liver ${ }^{d}$ \\
\hline HMC-Lr & high metastatic & liver $^{d}$ \\
\hline \multicolumn{3}{|l|}{ Teratocarcinoma cell line } \\
\hline $\mathrm{PCC} 4_{\mathrm{c}}-\mathrm{B}$ & nonmetastatic & - \\
\hline $\mathrm{PCC}_{4}-\mathrm{P}$ & nonmetastatic & - \\
\hline $\mathrm{PCC}_{\mathrm{c}}-107$ & nonmetastatic & - \\
\hline $\mathrm{C} 12-$ & nonmetastatic & - \\
\hline Embryocarcinoma, T-36 & $50 \%$ & lymph node \\
\hline Cell line derived from $T-36, T-36_{c}$ & $50 \%$ & lymph node \\
\hline Embryocarcinoma, LMEC & high metastatic & lymph node \\
\hline Teratocarcinoma, T-9 & low metastatic & lymph node \\
\hline Colon adenocarcinoma, Acatol & nonmetastatic & - \\
\hline Melanoma, B-16 & low metastatic & lung \\
\hline Lung carcinoma, RL-67 & high metastatic & lungd \\
\hline Lewis lung carcinoma, LLC & high metastatic & lung \\
\hline
\end{tabular}

a $\mathrm{PCC} 44_{c}-\mathrm{B}, \mathrm{PCC} 4 \mathrm{c}-\mathrm{P}$, and $\mathrm{PCC} 4 \mathrm{c}-107$ are cell lines derived from PCC4-Blangy, PCC4-Pasteur, and PCC4-107 teratocarcinomas.

b Low metastatic indicates $20 \%$ of injected mice give rise to solitary metastases.

c High metastatic indicates $100 \%$ of multiple metastases in target organs.

d Metastases in other organs.

that have a high level of $m t s 1$ expression demonstrate a high degree of metastasis, and the cells that do not express $m t s 1$ or express it at a low level either do not metastasize or have a low metastatic potential (CSML-50). The one exception we did find was HMC-Lr, a highly metastatic tumor in which mts1 is expressed at a low level. Perhaps another regulatory mechanism operates in this particular tumor to convert the cells to the metastatic phenotype.

Our data suggest that $m t s 1$ is involved in regulating the metastatic behavior of tumor cells. An increase in the transcription of some genes or in the expression of some proteins suggests that these genes may participate in the processes of tumor growth and metastases. For instance, a high level of ras gene expression in NIH-3T3 cells transformed with an activated c-Ha-ras oncogene correlates with the metastatic potential of these cells in nude mice (Bernstein and Weinberg 1985; Thorgeirsson et al. 1985).

Recently Collard and co-workers (1987) have shown that fusion of nonmetastatic T-lymphoma cells with normal $\mathrm{T}$ lymphocytes results in the formation of hybrid $\mathrm{T}$ cells with a high metastatic potential. Therefore, it is relevant to note that we found transcription of mts1 not only in tumor, but also in normal cells. Homologous RNA was found only in spleen, thymus, bone marrow, and blood lymphocytes. Thus, the finding that mts1 gene expression correlates with the metastatic potential of tumor cells expressed specifically in normal blood cells suggests that properties peculiar to some normal cells can contribute to formation of the metastatic phenotype.

The data on the amount of mRNA corresponding to $m t s 1$ or its analogs pEL98 and 18A2 are rather conflicting. Jackson-Grusby and co-workers (1987) have found a low but detectable level of the 18A2 gene expression in kidney and a very low amount of mRNA in thymus. In contrast, Goto's (1988) as well as our data do not show any detectable signals on Northern blot analysis of mRNA from kidney. In addition, we observed a low level of $m t s 1$ mRNA expression in thymus. The amounts of mRNA corresponding to the pEL98 and $18 \mathrm{~A} 2$ genes in primary embryo fibroblasts were also different. This discrepancy may be due to different mouse strains used in the experiments. However, the ability of the mouse probe to cross-hybridize with DNA sequences from human and other species points to the conservation of $m t s 1$ sequences.

Several mechanisms have been proposed for regulation of gene expression, including a different reorganization of the cell genome (Yokota et al. 1986). Restriction enzyme digests of genomic DNA from the normal mouse liver and the CSML-100 cell line hybridized to the mts 1 probe reveal only one fragment in each digest, which suggests that $m t s 1$ is a single-copy gene. Furthermore, identical hybridization patterns in both the normal liver and CSML-100 digests indicate that the high expression of mts1 in metastatic cells does not result from a gene translocation as well as from a gene amplification event, because the intensities of hybridization signals appear to be the same.

DNA methylation can also be an important mechanism regulating gene expression. The presence of 5methylcytidine in the $5^{\prime}$ promoter regions of genes is associated with the inactivation of transcription. The content of 5-methylcytidine in tumors has been found to be 


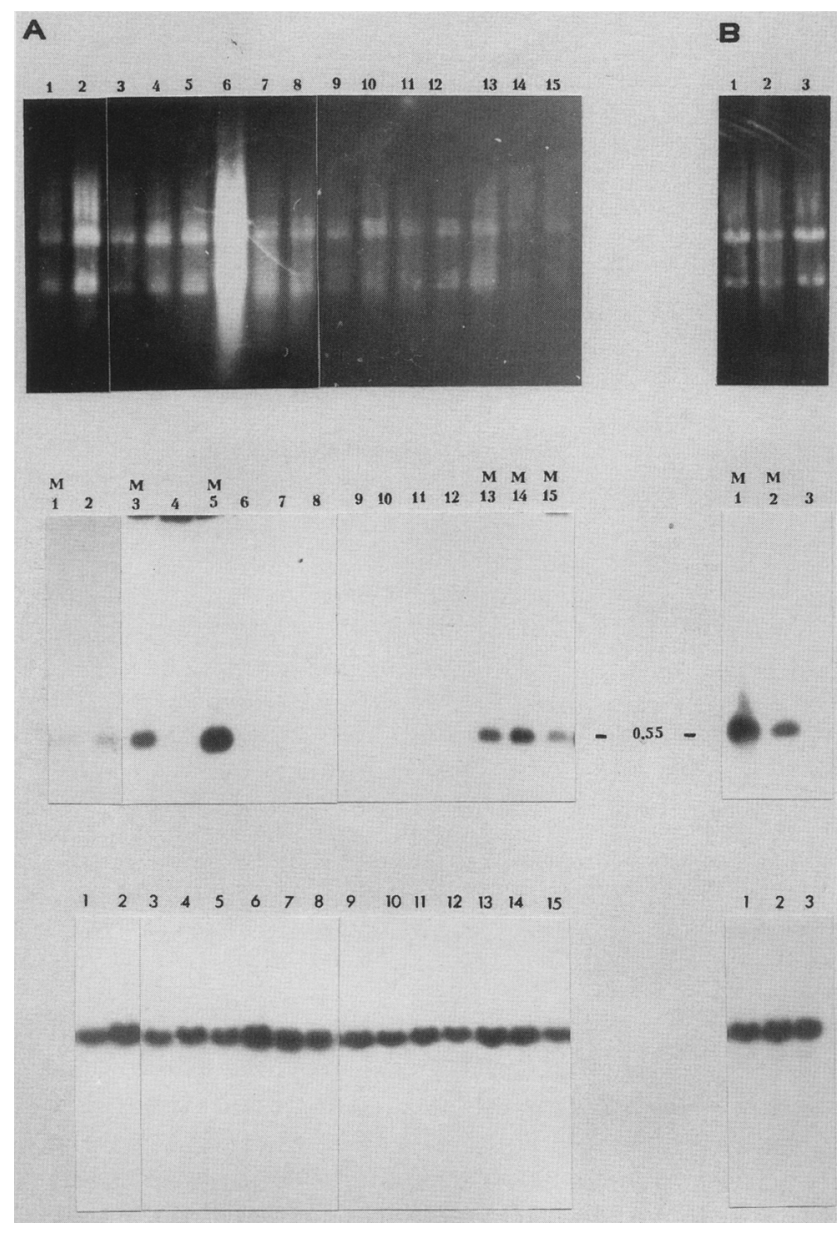

Figure 3. Northern analysis of total RNA from different metastatic and nonmetastatic mouse tumors and cell lines using $m t s 1$ DNA as a probe. The numbers indicate different tumors and cell lines. $(A)$ Three days autoradiography: (lane 1) HMCLr; (lane 2) HMC-0; (lane 3) RL-67; (lane 4) B-16; (lane 5) LLC; (lane 6) Acatol; (lane 7) C12; (lane 8) PCC4 $-\mathrm{B}_{\text {; }}$ (lane 9) PCC4 P $_{\mathrm{c}} \mathrm{P}$; (lane 10) PCC4 -107 ; (lane 11) PCC4 107; (lane 12) T9; (lane 13) LMEC; (lane 14) T-36; (lane 15) T-36 l. (B) Twelve hours autoradiography: (lane 1) CSML-100; (lane 2) CSML-50; (lane 3) CSML-0. $M$ indicates metastatic tumors. Ethidium bromide staining of the agarose gels is shown at the top of the figure. The amount of RNA loaded per gel lane was $20 \mu \mathrm{g}$. Hybridization with the actin probe is shown at the bottom of the figure.

lower than in normal cells (Feinberg and Vogelstein 1983). The treatment of nonmetastatic cells with 5-azacytidine makes the cells metastatic (Olsson and Forchhammer 1984; Litepto and Kerbel 1987). In the present study, we have found that $m t s 1$ transcription does not depend on DNA methylation. The mts1-specific RNA cannot be detected in nonmetastatic cells before and after 5-azacytidine treatment.

DNA sequencing of mts1 revealed two ORFs containing the information for peptides composed of 38 and 101 amino acids. However, the Kozak consensus sequences (Kozak 1984) flanking the translational start were found only for the large peptide (101 amino acids). The start region of the short peptide ( 38 amino acids) does not contain such sequences, and probably the ORF for this peptide is not functional.

Comparison of the amino acid sequences of the $m t s 1$ product revealed homology with the family of $\mathrm{Ca}^{2+}$. binding proteins (CaBPs). A common structural organization has been postulated for the $\mathrm{Ca}^{2+}$-binding site of the large CaBPs family by Szebenyi et al. (1981). These authors describe each calcium-binding site as being organized into a structure referred to as an EF hand and composed of a loop with two helical structures, one on either side. Sixteen amino acids in the sequences made of 29 residues are essential for the formation of a calcium-binding EF hand. Kretsinger (1976) has predicted that intracellular calcium-modulated proteins contain an EF hand and, vice versa, any protein with an EF hand is calcium-modulated. The structure of the $m t s 1$ protein product is shown in Figure 5B, and the sequences of some calcium-binding proteins are aligned with those of an EF hand. Although the mts1 protein has a $55 \%$ homology with the S-100 protein, all the residues present in the EF hand meet the proposed requirements. The two loops (residues 21-23 and 63-74) are remarkably conserved. In contrast, many differences are found in the linker regions and in the helices at positions where any amino acid may appear. On the whole, the structure of the $m t s 1$ protein product reported here fits in well with the EF hand theory, thus, identifying it as a member of the calcium-modulated protein family.

Neoplastic transformation is known to alter the expression pattern for the various members of this $\mathrm{Ca}^{2+}$ modulated protein family. For example, S-100 protein has been found in human melanoma cells (Gaynor et al. 1980 ), and in rodent fibroblasts transformed with RSV or SV40 viruses the amount of calmodulin is twice the normal level (Chatouleas et al. 1981). Oncomodulin, another $\mathrm{Ca}^{2+}$-binding protein, is expressed in significant

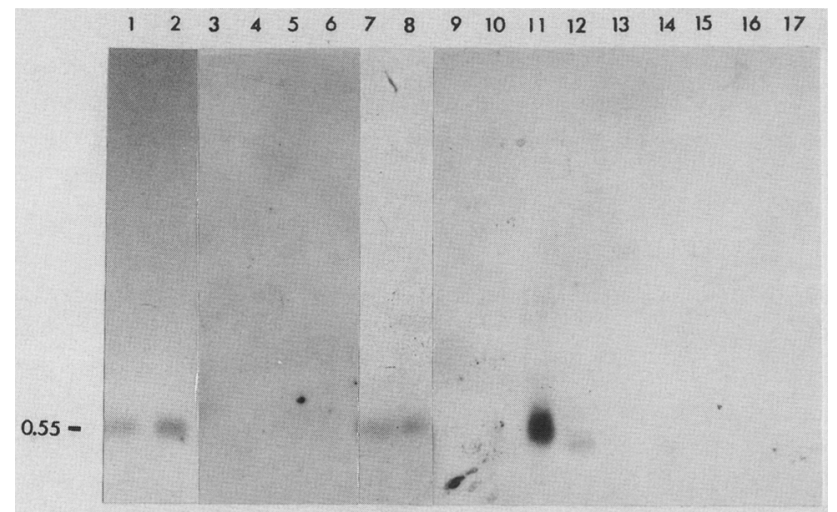

Figure 4. Northern blot analysis of total RNA from different organs of $\mathrm{A} / \mathrm{Sn}$ mice using mts1 DNA as a probe. The lane numbers indicate different organs: (lane 1) bone marrow; (lane 2) lymphocytes; (lane 3) female liver; (lane 4) male liver; (lane 5) female brain; (lane 6) male brain; (lane 7) male spleen; (lane 8) female spleen; (lane 9) male salivary glands; (lane 10) female salivary glands; (lane 11) male thymus; (lane 12) female thymus; (lane 13) female heart; (lane 14) female lung; (lane 15) male kidney; (lane 16) testis; (lane 17) ovary. Seven days autoradiography. 


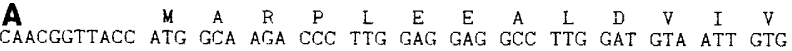
$\begin{array}{cccccccccccccccc}S & T & F & H & k & Y & S & G & K & E & G & D & K & F & K & I \\ T C C & \text { ACC } & \text { TTC } & \text { CAC } & \text { AAA } & \text { TAC TCA } & \text { GGC } & \text { AAA } & \text { GAG } & G G T & \text { GAC } & \text { AAG } & \text { TTC AAG } & \text { CTG }\end{array}$

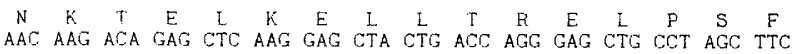
$\begin{array}{cccccccccccccccc}I & G & K & R & T & D & E & A & A & F & Q & K & V & M & S & N \\ \text { CTG GGG } & \text { AAA } & \text { AGG } & \text { ACA } & \text { GAT } & \text { GAA } & \text { GCT } & \text { GCA } & \text { TTC CAG } & \text { AAG } & \text { GTG } & \text { ATG } & \text { AGC } & \text { AAC }\end{array}$

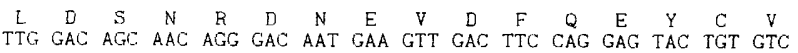

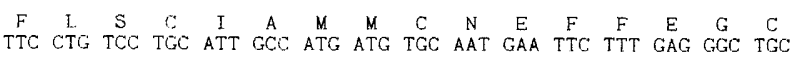
P D $K$ K E $P$ P $R \quad K \quad K$

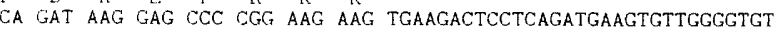
AGTTTGCCAGTGGGGGATCTTCCCTGTTGGCTGTGAGCATAGTGCCTTACTCTGGCTTCTTCG

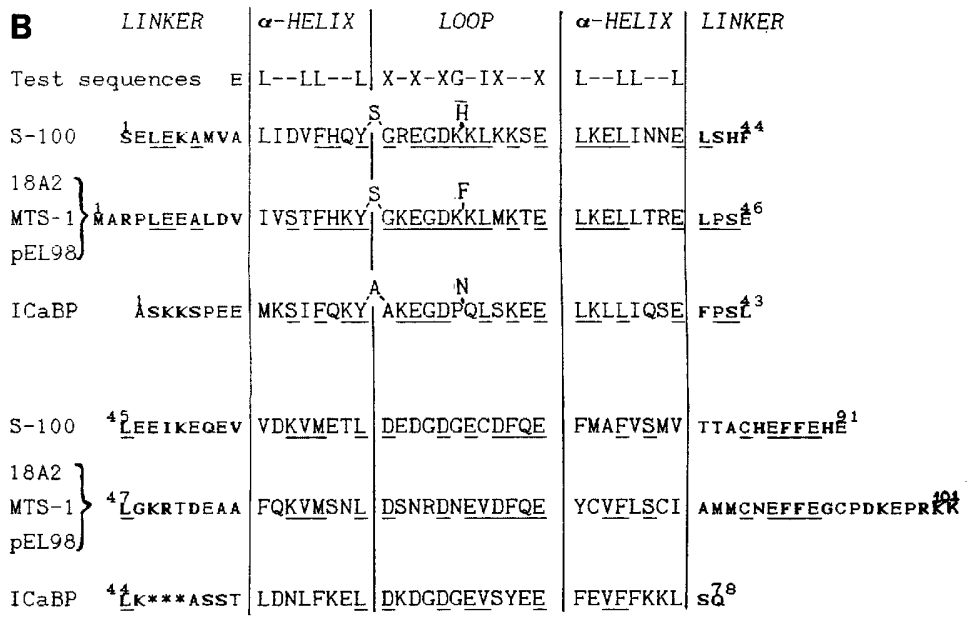

Figure 5. $(A \mid$ DNA sequence of $m t s 1 \mathrm{cDNA}$ and the deduced amino acid sequence. The putative polyadenylation signal is underlined. $(B)$ The homology of amino acid sequences in the EF hand region of some calcium-binding proteins. The test sequence represents residues suggested to be critical to the EF hand structure (Kretsinger 1976). (X) An oxygen-containing residue (D, E, N, Q, S, T); (L) a hydrophobic residue $(\mathrm{L}, \mathrm{V}, \mathrm{T}, \mathrm{K}, \mathrm{H})$; $(\mathrm{G})$ glycine; $(\mathrm{E})$ glutamic acid; (-) any amino acid appears in this position.

chemically induced rat hepatomas, but is not found in normal adult rat liver (Gillen et al. 1987). mRNA corresponding to the protein pEL98 is presented in large amounts in both chemically transformed and activated oncogene-transformed cell lines (Goto et al. 1988). mts1 is also expressed both in normal and transformed cells, but its level of expression in tumor cells is higher than in normal cells. Thus, this gene may have a significant diagnostic potential for metastatic disease; however, the delineation of its possible role in metastases awaits transfection of the full-length gene.

\section{Materials and methods}

Tumors and tumor cells

CSML-0 and CSML-100, as well as HMC-0 and HMC-Lr, are tumor lines established from spontaneous mammary adenocarcinomas of A/Sn mice (Senin et al. 1983, 1984). T-9 as well as T-36 and its variant LMEC are coupled sublines of two original tumors. The latter were induced by ectopic transplantation of 6-7 days' gestation syngeneic embryos to CBA/J and A/Sn mice (Senin et al. 1984).

Tumor cells were trypsinized, rinsed, and suspended in sterile Hanks' salt solution. A total of $1 \times 10^{6}$ cells in $0.3 \mathrm{ml}$ of Hanks' solution were injected subcutaneously into each 8- to 10 -week-old A/Sn mouse. Mice were examined weekly for the appearance of tumors. The resultant tumors were excised and used for DNA and RNA preparations.

Cell lines, $\mathrm{PCC} 44_{c}-\mathrm{P}, \mathrm{PCC} 4 \mathrm{c}-\mathrm{B}$, and $\mathrm{PCC} 4-\mathrm{c}-107$ were derived from PCC4-Blangy, PCC4-Pasteur, and PCC4-107 teratocarcinomas, respectively. All cell lines were maintained in Dulbecco's modified Eagle's medium (DMEM) containing 10\% fetal calf serum (FCS). Cells were passed weekly.

\section{Metastatic activity}

Metastatic activity was determined upon intramuscular injection of $1 \times 10^{6}$ tumor cells per tumor cell line in 10-15 mice. The mice were killed 4-5 weeks after tumor inoculation, and the number of lung metastases was counted. Nonmetastatic cell lines were defined as cell lines that did not result in visible metastases. Highly metastatic lines under the same conditions gave rise to multiple metastases in target organs of each mice.

\section{Nucleic acid purification and analysis}

Procedures for the preparation, analysis, and recombination in vitro of plasmid DNA were as described in Maniatis et al (1982). RNAs were prepared from different tumor cells and normal cells according to the procedure described by Chomczynski and Sacchi (1987). Gel electrophoresis, RNA blotting to nylon membrane filters, and hybridization with nick-translated DNA probes were as in Grigorian et al. \{1985). Total DNA was prepared from cells according to Maniatis et al. (1982). Southern blots were performed using $10 \mu \mathrm{g}$ of genomic DNA extracted from mouse liver, CSML-100 cells, human placenta and liver, rat liver, pig liver, and chicken liver. DNAs were digested with BamHI, EcoRI, and PstI endonucleases. Following electrophoresis in a $0.8 \%$ agarose gel, the DNA was transferred onto a nylon membrane (Hybond N, Amersham). The filter was prehybridized and hybridized following a standard procedure (Maniatis et al. 1982). The nucleotide sequences of $m t s 1$ were determined using the chemical degradation procedure of Maxam and Gilbert (1980).

\section{CDNA/RNA solution reassociation, construction, and screening of $C D N A$ libraries}

The PERT reaction (Kohne et al. 1977) employed cDNA synthesized with the aid of reverse transcriptase on poly(A) mRNAs (2 $\mu \mathrm{g}$ ) from the CSML-100 cell line and an excess of driver poly(A) mRNA $(50 \mu \mathrm{g})$ isolated from the CSML-0 cell line. The cDNA was heated at $100^{\circ} \mathrm{C}$ for $5 \mathrm{~min}$, cooled on ice, and added to the final reaction volume of $1 \mathrm{ml}$ in a 10-ml glass centrifuge tube in $7 \%$ phenol (adjusted to $\mathrm{pH} 7.6$ with $0.1 \mathrm{M}$ Tris- $\mathrm{HCl}, 1.25 \mathrm{M}$ $\mathrm{NaCl}, 120 \mathrm{~mm}$ sodium phosphate buffer, $\mathrm{pH} 6.8$ ). The tube was shaken for 7 days at $25^{\circ} \mathrm{C}$. After hybridization, the mixture was extracted twice with chloroform, then dialyzed against $10 \mathrm{mM}$ Tris- $\mathrm{HCl}(\mathrm{pH} 7.5), 1 \mathrm{mM}$ EDTA to remove excess salts, and then precipitated with ethanol. The PERT-reassociated ds-cDNA was mixed with $\lambda$ gt10 arms DNA and $1 \mu \mathrm{l}$ of T4 ligase (80 
$\mathrm{U} / \mathrm{ml}$, and the mixture was packaged in vitro into bacteriophage particles that were used for $E$. coli infection. The library was screened differentially with radioactively labeled firststrand products of the reverse transcriptase reaction using $1 \mu \mathrm{g}$ of poly $(\mathrm{A})^{+} \mathrm{mRNAs}$ from the CSML-100 and CSML-0 cell lines.

\section{Sequence homologies}

The homologous domains of the $m t s 1$ product were aligned using the protein alignment program PROTAN, followed by inspection.

\section{Acknowledgments}

The authors express grateful thanks to Professor G.P. Georgiev for continued stimulating discussions and to Dr. N.I. Milshina for her assistance in analyzing the hydropathy of proteins.

\section{References}

Barraclough, R., J. Savin, S.K. Dube, and P.S. Rudland. 1987. Molecular cloning and sequence of the gene for $\mathrm{p} 9 \mathrm{Ka}, \mathrm{a} \mathrm{cul}$ tured myoepithelial cell protein with strong homology to S100, a calcium-binding protein. J. Mol. Biol. 198: 13-20.

Berger, M.S., G.W. Locher, S. Saurer, W.Y. Gullick, M.D. Waterfield, B. Groner, and N.E. Hynes. 1988. Correlations of $c$-erb $\beta 2$ gene amplification and protein expression in human breast carcinoma with nodal status and nuclear grading. Cancer Res. 48: 1238-1243.

Bernstein, S.C. and R.A. Weinberg. 1985. Expression of the metastatic phenotype in cells transfected with human metastatic tumor DNA. Proc. Natl. Acad. Sci. 82: 1726-1730.

Cairns, J. 1981. The origin of human cancers. Nature 289: $353-$ 357.

Cavener, D.A. 1987. Comparison of the consensus sequence flanking translational start in Drosophila and vertebrates. Nucleic Acids Res. 15: 1353-1361.

Chatouleas, J.G., R.L. Pardue, B.R. Brinkley, J.R. Dedman, and A.R. Means. 1981. Regulation of intracellular levels of calmodulin and tubulin in normal and transformed cells. Proc. Natl. Acad. Sci. 78: 996-1000.

Chomczynski, P. and N. Sacchi. 1987. Single-step method of RNA isolation by acid guanidium thiocyanate-phenol-chloroform extraction. Anal. Biochem. 162: 156-159.

Collard, J.G., J.F. Schijven, and E. Roos. 1987. Invasive and metastatic potential induced by ras-transfection into mouse BW5147 T-lymphoma cells. Cancer Res. 47: 754-759.

Feinberg, A.P. and B. Vogelstein. 1983. Hypomethylation distinguishes genes of some human cancers from their normal counterparts. Nature 301: 89-92.

Foulds, L. 1975. Neoplastic development, vol. 2. Academic Press, London.

Gaynor, R., R. Irie, D. Morton, and H.R. Herchman. 1980. S100 protein is present in cultured human malignant melanomas. Nature 286: 400-401.

Gillen, M.F., D. Banville, R.G. Rutledge, S. Narang, V.L. Seligy, J.F. Whitefield, and J.F. MacManus. 1987. A complete complementary DNA for the oncodevelopmental calciumbinding protein oncomodulin. I. Biol. Chem. 262: 53085312.

Goto, K., H. Endo, and T. Fujiyoshi. 1988. Cloning of the sequences expressed abundantly in established cell lines: Identification of a cDNA clone highly homologous to S-100, a calcium binding protein. J. Biochem. 103: 48-53.
Grigorian, M.S., D.A. Kramerov, E.M. Tulchinsky, E.S., Revazova, E.M. Lukanidin. 1985. Activation of putative transposition intermediate formation in tumor cells. $E M B O \quad I$. 4: 2209-2215.

Jackson-Grusby, L.L., J. Swiergiel, and D.I.J. Linzer. 1987. A growth-related mRNA in cultured mouse cells encodes a placental calcium binding protein. Nucleic Acids Res. 15: 6677-6690.

Klein, J. and E. Klein. 1985. Evolution of tumors and the impact of molecular oncology. Science 315: 190-195.

Kohne, D.E., S.A. Levinson, and M.J. Byers. 1977. Room temperature method for increasing the rate of DNA reassociation by many thousand-fold: The phenol emulsion reassociation technique. Biochemistry 16: 5329-5341.

Kozak, M. 1984. Comparison of initiation of protein synthesis in procaryotes, eucaryotes and organelles. Microbiol. Rev. 47: $1-45$.

Kretsinger, R.H. 1976. Calcium-binding proteins. Annu. Rev. Biochem. 45: 239-266.

Kris, R.M., A. Aviv, M. Bar-Eli, Y. Alon, P. Carni, J. Schlessinger, and A. Raz. 1985. The expression of Ki-ras oncogene in tumor cell variants exhibiting different metastatic capabilities. Int. J. Cancer 35: 227-230.

Kunkel, L.M., A.P. Monaco, W. Middlesworth, M.D. Ochs, and S.A. Latt. 1985. Specific cloning of DNA fragments absent from the DNA of a male patient with a X-chromosome deletion. Proc. Natl. Acad. Sci. 82: 4778-4782.

Lamar, E.E. and E. Palmer. 1984. Y-encoded, species-specific DNA in mice: Evidence that the Y-chromosome exists in two polymorphic forms in inbred strains. Cell 37: 171-177.

Litepto, R.G. and R.S. Kerbel. 1987. Reduced levels of DNA 5methylcytosine in metastatic variants of the human melanoma cell line MeWo. Cancer Res. 47: 2264-2267.

Maniatis, T., E.F. Fritsch, and J. Sambrook. 1982. Molecular cloning: A laboratory manual. Cold Spring Harbor Laboratory, Cold Spring Harbor, New York.

Masiakowski, P. and E.M. Shooter. 1988. Nerve growth factor induces the genes for two proteins related to a family of calcium-binding proteins in PC12 cells. Proc. Natl. Acad. Sci. 85: $1277-1281$.

Maxam, A.M. and W. Gilbert. 1980. Sequencing end-labeling DNA with base-specific chemical cleavages. Methods Enzymol. 65: 499-537.

Nicolson, G.L. 1982. Cancer metastasis: Organ colonization and the cell-surface properties of malignant cells. Biochim. Biophys. Acta 695: 113-176.

. 1984. Generation of phenotype diversity and progression in metastatic tumors. Cancer Metast. Rev. 3: 24-42.

- 1987. Tumor cell instability, diversification and progression to the metastatic phenotype. Cancer Res. 47: 1473-1487.

Olsson, L. and J. Forchhammer. 1984. Induction of the metastatic phenotype in a mouse tumor model by 5 -azacytidine and characterization of an antigen associated with metastatic activity. Proc. Natl. Acad. Sci. 81: 3389-3393.

Rotter, V., D. Wolf, M. Blick, and G.L. Nicolson. 1985. Expression of $a b l$ and other oncogenes is independent of metastatic potential in Abelson virus-transformed malignant murine large lymphoma. Clin. Exp. Metastatis 3: 77-86.

Senin, V.M., A.M. Buntsevich, A.V. Afanasyeva, and N.S. Kiseleva. 1983. A new line of metastatic murine carcinosarcoma. Exp. Oncol. USSR 5: 35-38.

Senin, V.M., A.M. Ivanov, A.V. Afanasyeva, and A.M. Buntsevich. 1984. New organotropic-metastatic transplanted tumors of mice and their use for studying laser effect on dissimination. Vestnik USSR Acad. Med. Sci. 5: 85-91. 
Storer, R.D., H. L. Allen, A.R. Kraynak, and M.O. Bredly. 1988. Rapid induction of an experimental estastatic phenotype in first passage rat embryo cells by cotransfection of EF c-Haras and c-myc oncogenes. Oncogene 2: 141-147.

Szebenyi, D.M.E., K. Obendorf, and K. Moffat. 1981. Structure of vitamin D-dependent calcium-binding protein from bovine intestine. Nature 294: 327-332.

Thorgeirsson, U.P., T. Turpeenniemi-Hujanen, J.E. Williams, E.H. Westin, C.A. Heilman, J.E. Talmadge and L.A. Liotta. 1985. NIH 3T3 cells transfected with human tumor DNA containing activated ras oncogenes express the metastatic phenotype in nude mice. Mol. Cell. Biol. 5: 259-262.

Vousden, K.H. and D.J. Marshall. 1984. Three different activated ras genes in mouse tumors: Evidence for oncogene activation during progression of a mouse lymphoma. EMBO $J$. 3: 913-917.

Vousden, K.H., S.H. Eccles, H. Purvies, and C.J. Marshall. 1986. Enhanced spontaneous metastasis of mouse carcinoma cells transfected with an activated c-Ha-ras gene. Int. I. Cancer. 37: 425-433.

Yokota, J., Y. Tsunetsugu-Yokota, H. Battifora, C. Le Fevre, and M.J. Cline. 1986. Alteration of $m y c, m y b$, and ras ${ }^{H a}$ protooncogenes in cancers are frequent and show clinical correlation. Science 231: 261-265. 


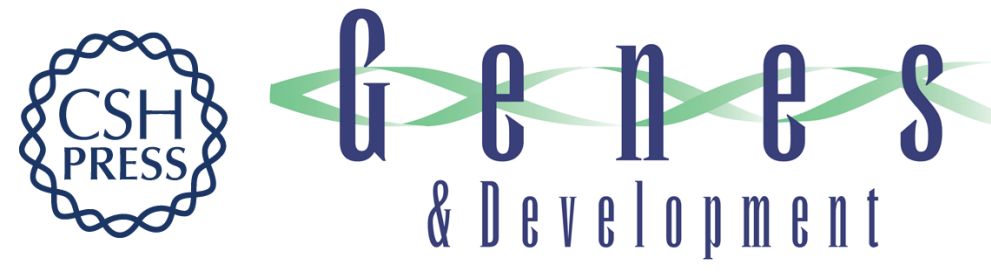

\section{Isolation and characterization of a gene specifically expressed in different metastatic cells and whose deduced gene product has a high degree of homology to a Ca2+-binding protein family.}

A Ebralidze, E Tulchinsky, M Grigorian, et al.

Genes Dev. 1989, 3:

Access the most recent version at doi:10.1101/gad.3.7.1086

References This article cites 37 articles, 12 of which can be accessed free at: http://genesdev.cshlp.org/content/3/7/1086.full.html\#ref-list-1

License

Email Alerting Service

Receive free email alerts when new articles cite this article - sign up in the box at the top right corner of the article or click here.

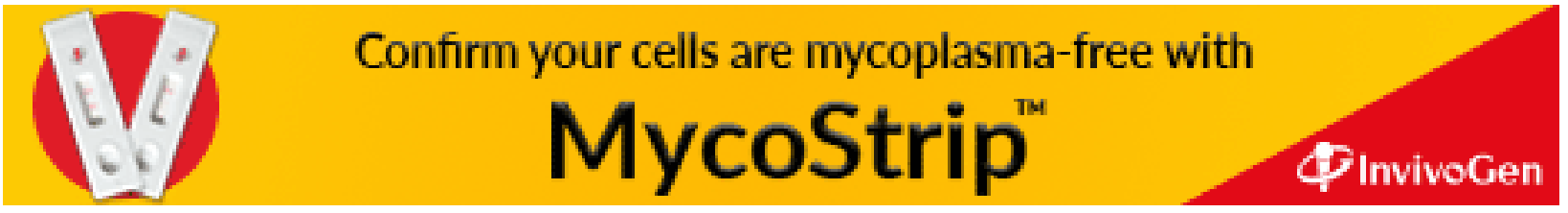

